\title{
Postoperative complications in adult patients undergoing surgery with confirmed infection by SARS-CoV-2: An integrative review
}

\author{
Erica Favaro \\ (1D) https://orcid.org/0000-0003-3060-0288 \\ Daiane Rubinato Fernandes ${ }^{1,2}$ \\ (iD) https://orcid.org/0000-0002-9363-0057 \\ Leticia Genova Vieira1,3 \\ (D) https://orcid.org/0000-0002-9780-4309 \\ Amanda Salles Margatho ${ }^{1}$ \\ (1D) https://orcid.org/0000-0002-1006-9357 \\ Karina Dal Sasso Mendes ${ }^{1}$ \\ (D) https://orcid.org/0000-0003-3349-2075 \\ Renata Cristina de Campos Pereira Silveira ${ }^{1}$ \\ (D) https://orcid.org/0000-0002-2883-3640
}

\begin{abstract}
Objective: to analyze the evidence available in the literature about postoperative complications in adult patients undergoing surgical procedures with confirmed infection by SARSCoV-2. Method: an integrative literature review conducted in the CINAHL, EMBASE, LILACS, PubMed, Scopus and Web of Science databases, as well as in the gray literature. The references identified were exported to the EndNote manager and, subsequently, to the Rayyan web application for study selection. The stages of sampling, categorization of studies, evaluation of the studies included, interpretation of the results and knowledge synthesis were performed by two reviewers independently and in a masked manner. The data were analyzed descriptively. Results: of the 247 articles identified, 15 were selected to comprise this review. The prevalent postoperative complications in patients infected with SARS-CoV-2 were the following: cough, dyspnea and hypoxia, need for invasive mechanical ventilation or not, admission to the intensive care unit and death. Conclusion: the most reported postoperative complications in the studies evaluated were respiratory-related, followed by cardiovascular complications. The importance of preoperative screening for COVID-19 is highlighted, as well as of the monitoring and tracking of confirmed cases in the postoperative period, as these actions exert an impact on reducing the occurrence of complications related to SARSCoV-2.
\end{abstract}

Descriptors: Postoperative Complications; Coronavirus Infections; SARS-CoV-2; Adult; Perioperative Nursing; Review Literature as Topic.

\section{How to cite this article}

Favaro E, Fernandes DR, Vieira LG, Margatho AS, Mendes KDS, Silveira RCCP. Postoperative complications in adult patients undergoing surgery with confirmed infection by SARS-CoV-2: An integrative review. Rev. Latino-Am. Enfermagem. 2021;29:e3496. [Access $\underset{\text { month }}{\frac{1}{1}} \frac{1}{1}$ ] $]$; ; Available in: DOI: http://dx.doi.org/10.1590/1518-8345.5346.3496 


\section{Introduction}

The Coronavirus 2019 disease (COVID-19) was first identified in Wuhan, province of Hubei, China, in December 2019, and quickly spread around the world. In March 2020, it was declared a pandemic by the World Health Organization (WHO). It is an infectious disease caused by the etiological agent called Coronavirus 2 of Severe Acute Respiratory Syndrome (Coronavirus 2 - SARS-CoV-2)(1).

The clinical manifestations caused by COVID-19 are usually related to the upper respiratory tract, with the majority of those infected being asymptomatic or with mild symptoms. The most frequent clinical signs and symptoms are fever, dry cough, myalgia or fatigue and dyspnea and, less frequently, headache, diarrhea, nausea, vomiting, anosmia, dysgeusia and sore throat. Some patients can develop lower respiratory tract infections. However, infections can progress to pneumonia with Severe Acute Respiratory Syndrome (SARS), renal failure, multiple organ dysfunction syndrome and death(2-4).

Given the high rates of infection and transmissibility, there was a significant increase in patients with acute diseases, which overloaded health systems around the world, especially hospitals, which were not prepared to deal with the magnitude of care and resources required by this pandemic. Overcrowding of the Intensive Care Units and overload of health professionals were inevitable, requiring the rapid adaptation of the surgical sectors ${ }^{(5-9)}$.

To relieve pressure on the health system and minimize the risk of nosocomial spread of COVID-19 during surgical procedures, specialized societies determined that elective surgical interventions be suspended or postponed. However, urgent and emergency procedures, as well as those with urgent surgical indication, should undergo a careful assessment on a case-by-case basis, to analyze the risk of transmission and postoperative complications ${ }^{(9-10)}$. In addition to that, measures to prevent and avoid the spread of the virus within the surgical environment highlighted the correct use of personal protective equipment and the reduction in the transit of personnel within operating rooms during invasive procedures ${ }^{(2,8)}$.

Studies evaluating the impact of postoperative complications in patients infected with SARS-CoV-2 are still scarce in the literature. Despite this, it was evidenced that, due to proinflammatory cytokine and immunosuppressive responses related to surgery and mechanical ventilation, such patients are especially susceptible to subsequent pulmonary complications, changes in laboratory tests, acute kidney injury, arrhythmia, acute cardiac injury, shock and secondary infections ${ }^{(11-14)}$.

Identifying postoperative complications early is relevant to reduce morbidity and mortality in this period. A number of studies show that previously undiagnosed
COVID-19 can complicate postoperative recovery ${ }^{(13,15)}$. In this sense, the importance of the Nursing team in the post-anesthetic recovery room and in the inpatient units is highlighted, as this is the professional category that stays the longest with the patient, being responsible for evaluating complications and implementing interventions aimed at preventing problems and promoting health recovery ${ }^{(13,15)}$.

Despite the publication of guidelines to guide the ways of reorganizing surgical activities during the COVID-19 pandemic, the scientific production related to the management of surgeries is incipient, particularly with regard to the treatment of postoperative complications. Added to this context, the nurse is the protagonist to early identify the clinical manifestations that may be related to such adversities and make evidence-based clinical decisions to solve them. Thus, synthesizing the evidence to increase the safety of surgical patients exposed to SARS-CoV-2 is urgent and necessary, with the potential to directly influence the clinical outcomes of these patients. For this reason, this study aimed at analyzing the evidence available in the literature on postoperative complications in adult patients undergoing surgical procedures with confirmed infection by SARS-CoV-2.

\section{Method}

\section{Study type}

This study consists of an integrative literature review, filed on the Open Science Framework platform, whose registration is available at https://osf.io/be97s/, which enables to gather and synthesize the production of knowledge on a given subject matter, ensuring, through the wide number of studies, theoretical deepening on different perspectives of the same theme ${ }^{(16)}$. The study was conducted in six stages ${ }^{(16)}$, namely: identification of the theme, sampling, categorization of the studies, evaluation of the studies included, interpretation of the results and knowledge synthesis, respectively. The question of this integrative review was guided by the PECO strategy $^{(17)}$ (Figure 1) and consisted of: Which are the postoperative complications in adult patients undergoing surgical procedures with confirmed infection by SARSCoV-2?

\begin{tabular}{|c|l|l|}
\hline Acronym & \multicolumn{1}{|c|}{ Definition } & \multicolumn{1}{|c|}{ Description } \\
\hline $\mathbf{P}$ & $\begin{array}{l}\text { Population/ } \\
\text { Problem }\end{array}$ & $\begin{array}{l}\text { Adult patients undergoing elective } \\
\text { surgeries }\end{array}$ \\
\hline E & Exposure & Confirmed infection by SARS-CoV-2 \\
\hline C & Comparison & Does not apply \\
\hline $\mathbf{O}$ & Outcome & Postoperative complications \\
\hline
\end{tabular}

Figure 1 - PECO strategy to formulate the research question. Ribeirão Preto, SP, Brazil, 2020 


\section{Data collection}

To identify the studies, the following electronic databases were used: CINAHL, EMBASE, LILACS, PubMed, Scopus and Web of Science. The gray literature was consulted using Google Scholar. The search strategy was formulated with the combination of the following controlled descriptors and/or keywords "Postoperative Complications", "Coronavirus Infections", "COVID-19" and their respective synonyms, combined with Boolean operators (AND and OR), and adapted according to the specifics of each database. The search strategy conducted in each database is described in Figure 2.

\begin{tabular}{|c|c|c|}
\hline Database & Search strategies & $\begin{array}{c}\text { Number of studies } \\
\text { identified }\end{array}$ \\
\hline PubMed & $\begin{array}{l}\text { ("Postoperative Complications"[Mesh] OR "Postoperative Complications"[All fields] OR } \\
\text { "Postoperative Complication") AND ("Coronavirus Infections"[Mesh] OR "Coronavirus } \\
\text { Infections"[All Fields] OR "COVID-19" OR "SARS-CoV-2" OR "2019-nCoV infection" OR "2019 } \\
\text { novel coronavirus infection" OR "coronavirus disease-19" OR } \\
\text { "2019-nCoV disease") Filters: from } 2019 \text { - } 2020\end{array}$ & 82 studies \\
\hline LILACS & $\begin{array}{l}\text { ("Postoperative Complications" OR "complicaciones posoperatorias" OR "complicações } \\
\text { pós-operatórias" OR "Postoperative Complication" OR "complicação pós-operatória OR } \\
\text { "complicación postoperatoria") AND ("coronavirus infections" OR "infecciones por coronavirus" } \\
\text { OR "infecções por coronavirus" OR "covid 19") AND (db:("IBECS")) }\end{array}$ & 1 study \\
\hline EMBASE & $\begin{array}{l}\text { ('postoperative complications'/exp OR 'postoperative complications' OR 'postoperative } \\
\text { complication'lexp OR 'postoperative complication') AND ('coronavirus infections'/exp OR } \\
\text { 'coronavirus infections' OR 'covid-19'/exp OR 'covid-19' OR 'sars-cov-2'/exp OR 'sars-cov-2' } \\
\text { OR '2019ncov infection'/exp OR '2019-ncov infection' OR '2019 novel coronavirus infection' } \\
\text { OR 'coronavirus disease-19' OR '2019-ncov disease'/exp OR '2019-ncov disease') AND } \\
\text { [embase]/lim NOT ([embase]/lim AND [medline]/lim) }\end{array}$ & 55 studies \\
\hline CINAHL & $\begin{array}{l}\text { (("Postoperative Complications" OR "Postoperative Complications" OR "Postoperative } \\
\text { Complication") AND ( } \\
\text { "Coronavirus Infections" OR "Coronavirus Infections"” OR } \\
\text { "COVID-19" OR "SARS-CoV-2" OR "2019-nCoV infection" OR "2019 novel coronavirus } \\
\text { infection" OR } \\
\text { "coronavirus disease-19" OR "2019-nCoV disease") }\end{array}$ & 10 studies \\
\hline Scopus & $\begin{array}{l}\text { (TITLE-ABS-KEY ("Postoperative Complications" OR } \\
\text { "Postoperative Complications" OR "Postoperative Complication") AND TITLE-ABS-KEY } \\
\text { ("Coronavirus } \\
\text { Infections" OR "Coronavirus Infections" OR "COVID-19" OR "SARS-CoV-2" OR "2019-nCoV } \\
\text { infection" OR "2019 novel coronavirus infection" OR "coronavirus disease-19" OR "2019-nCoV } \\
\text { disease") ) AND ( LIMIT-TO ( PUBYEAR, 2020)) }\end{array}$ & 88 studies \\
\hline Web of Science & $\begin{array}{l}\text { (("Postoperative Complications" OR "Postoperative Complications" OR "Postoperative } \\
\text { Complication") AND( } \\
\text { "Coronavirus Infections" OR "Coronavirus Infections"” OR } \\
\text { "COVID-19" OR "SARS-CoV-2" OR "2019-nCoV infection" OR "2019 novel coronavirus } \\
\text { infection" OR } \\
\text { "coronavirus disease-19" OR "2019-nCoV disease") }\end{array}$ & 11 studies \\
\hline Google Scholar & $\begin{array}{l}\text { ("Postoperative Complications" OR "Postoperative Complication") AND ("Coronavirus } \\
\text { Infections" OR "COVID-19" OR "SARS-CoV-2" OR "2019-nCoV infection" OR "2019 novel } \\
\text { coronavirus infection" OR "coronavirus disease-19" OR "2019-nCoV disease") Filters: from } \\
2019-2020\end{array}$ & 100 studies \\
\hline
\end{tabular}

Figure 2 - Search strategies used in the databases used. Ribeirão Preto, SP, Brazil, 2020

After the search, the results were exported to the EndNote Basic ${ }^{(18)}$ reference manager, online version, to remove duplicate references. Subsequently, they were imported into the Rayyan web application, which can be accessed through https://rayyan.qcri.org, for the selection of studies.

In the Rayyan web application, the studies were evaluated and selected by two reviewers independently and blindly, first by reading the titles and abstracts, in order to verify if they met the eligibility criteria of this review. The studies considered eligible were then analyzed by reading the text in its entirety, according to the eligibility criteria. In case of disagreement between the reviewers, a third reviewer with expertise in the subject matter was consulted. 


\section{Period}

The search in the electronic databases was carried out on August $19^{\text {th }}, 2020$.

\section{Selection criteria}

Primary studies addressing postoperative complications occurring in adult patients undergoing surgery and infected with COVID-19, published in Portuguese, English or Spanish, were included. Studies conducted with pediatric patients, conference proceedings and abstracts, and studies that did not meet the scope of this review were excluded.

A total of 247 studies were identified in the databases, of which 87 were excluded for being duplicates in at least two databases, totaling 160 studies. Among the 160 studies identified and evaluated by reading titles and abstracts, 96 were excluded for not meeting the eligibility criteria of this review. Of the 64 studies eligible for analysis by reading the text in its entirety, 15 were included in this review. At the end of the selection process, a manual search was carried out in the list of references of the included studies. However, it did not identify publications that could be included in the final review sample. Thus, the final sample consisted of 15 primary studies.

\section{Instrument used to collect the information}

The data from the studies were collected using an adapted form ${ }^{(19)}$, which includes the following: reference and year of publication, country where the study was conducted, methodological characteristics [study design according to the nomenclature used by the author(s) and sample] and main outcomes (postoperative complications).

\section{Data treatment and analysis}

The data were analyzed qualitatively, synthesizing the evidence from the primary studies in a descriptive way.
For the critical evaluation stage, it was decided to assess the methodological quality of the primary studies included in the sample, using the tools provided by the Joanna Briggs Institute (JBI) ${ }^{(20)}$, also independently, by two reviewers. This evaluation was carried out considering the appropriate tools for each type of design included, which can present "yes", "not clear", "no" or "not applicable" answers. Before initiation of the critical evaluation of the studies, decisions about the scores were agreed upon between the reviewers. The studies included were categorized for risk of bias as follows: high risk of bias (when it reached a "yes" score below 49\%), moderate risk of bias (when the "yes" score reached 50\% to 69\%), and low risk of bias (when the study reached a "yes" score above $70 \%)^{(21)}$. The third reviewer was consulted in case of conflicts in the assessment between the first two reviewers.

Considering that it is fundamental to unite methodological quality and the strength of the evidence for decision-making in the clinical practice, the evaluated studies were classified according to the level of evidence, according to the hierarchy for clinical issues of prognosis/ prediction or etiology, which varies from level I (evidence from synthesis of cohort studies or case-control studies) to level $\mathrm{V}$ (evidence from experts' opinion) ${ }^{(22-23)}$.

\section{Results}

This integrative review analyzed 15 primary studies that identified postoperative complications in adult patients undergoing surgeries with confirmed SARS-CoV-2 infection, which were published in 2020, in English $(n=14)$ and Spanish $(n=1)$, in international journals. The flowchart corresponding to the selection of studies can be seen in Figure 3.

The analysis allowed identifying four articles characterized as cohort studies ${ }^{(9,24-26)}$, three cross-sectional studies $^{(27-29)}$, three case reports(30-32), two retrospective studies $^{(15,33)}$, two case series ${ }^{(34-35)}$ and a letter to the editor $^{(36)}$. 


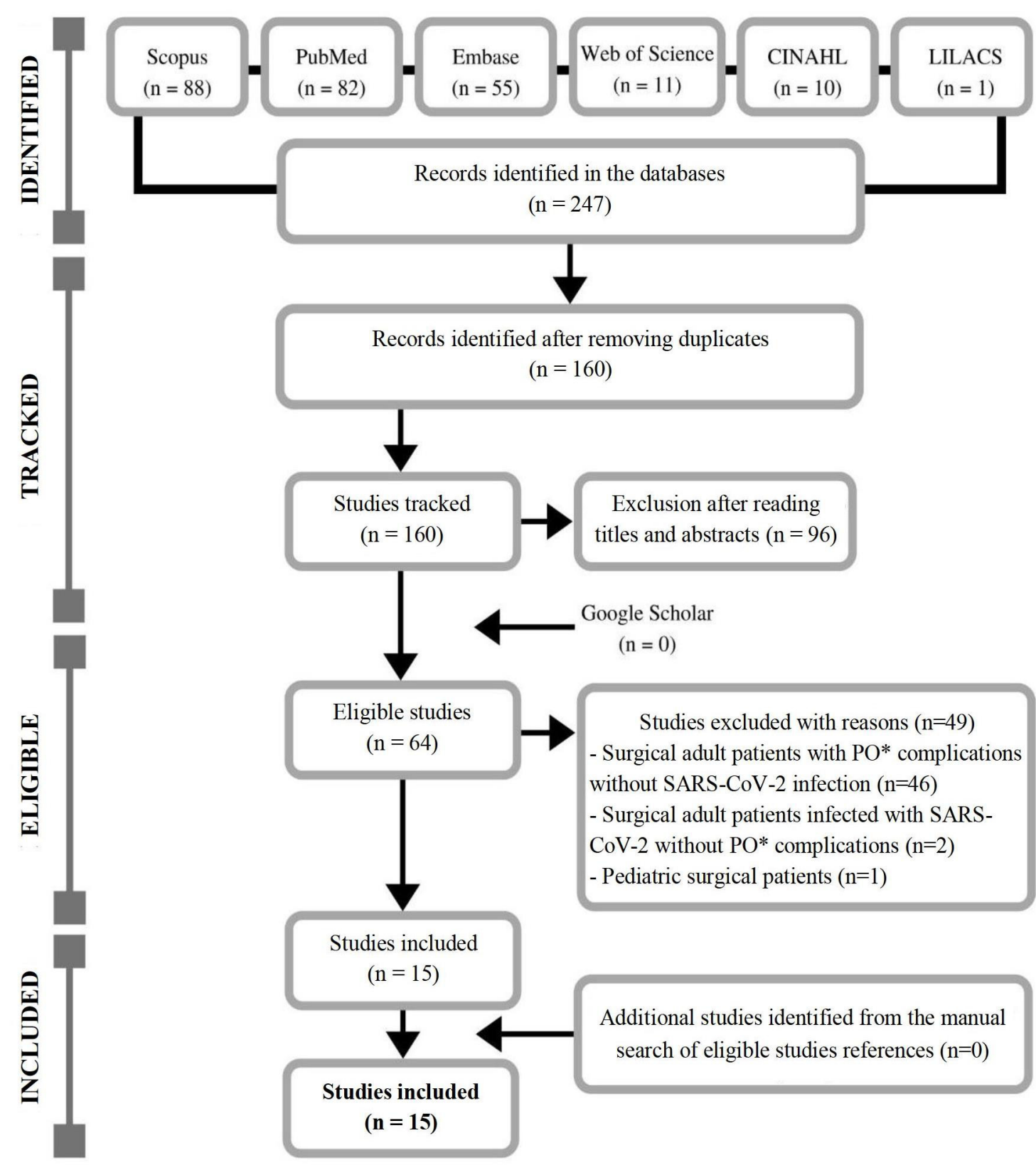

$* \mathrm{PO}=$ Postoperative

Figure 3 - Adaptation of the study selection flowchart of this integrative review $(n=15)$, according to the Preferred Reporting Items for Systematic Reviews and Meta-Analyses (PRISMA) model(37). Ribeirão Preto, SP, Brazil, 2020

Figure 4 presents the general synthesis of the studies included in this review by author, year of publication, country, method, objective, main results (herein represented by the postoperative complications in adult patients infected with SARS-CoV-2), methodological quality and level of evidence.

The main postoperative complications identified in the primary studies were related to the respiratory

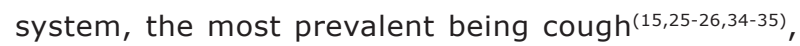
dyspnea(26,31,34), hypoxia(25,31,34-35), severe respiratory failure ${ }^{(24,28,33)}$, pulmonary embolism ${ }^{(9,28-29)}$ and severe respiratory infection requiring invasive or non-invasive mechanical ventilation ${ }^{(9,25-26,34)}$.

Patients with confirmed infection by SARS-CoV-2 presented changes in their imaging exams, compatible with pneumonia caused by COVID-19, such as groundglass opacity, nodular consolidations in lobules and pleural effusion(25-26,30,32,35-36). Changes in laboratory tests evidenced metabolic acidosis(24), coagulation disorders ${ }^{(24,29-30)}$ and acute kidney injury ${ }^{(24)}$.

A number of studies emphasize the importance of preoperative screening for COVID-19 for all patients, in 
order to exclude the possibility of infection, considering the incubation period of the virus for patients with negative results ${ }^{(32,35)}$. Some authors report difficulty in diagnosing postoperative SARS-CoV-2 infection(30,36), as the symptoms are similar to those of common postoperative complications, such as increased body temperature ${ }^{(15,25-26,30-32,35)}$.

Other complications observed were related to the cardiovascular system, including acute myocardial infarction ${ }^{(24)}$, hypotension ${ }^{(25)}$, acute cardiac injury ${ }^{(15)}$ and cardiac arrhythmia(15,28). In addition to that, cases of septic shock $^{(24)}$, urinary tract infection ${ }^{(28,34)}$ and multiple organ dysfunction were observed ${ }^{(15,24)}$.
The studies also evidenced cases of need for second surgeries $^{(9)}$, unplanned admission to the $\operatorname{ICU}(9,15,34)$ and death $^{(15,25-26,29,33-34,36)}$, resulting from worsening of the postoperative complications among patients with confirmed SARS-CoV-2 infection.

Regarding the methodological quality of the primary studies included, eight were classified as with low risk of bias and, therefore, they present good methodological quality. Six studies were classified as with moderate risk of bias and moderate methodological quality, and only one as with high risk of bias and low methodological quality. Regarding the level of evidence, four studies presented level II, seven were level IV and four, level V.

\begin{tabular}{|c|c|c|c|c|c|}
\hline ID $^{*}$ & Method & Objective & Main Results (postoperative complications) & $\mathrm{JBI}^{\dagger}$ & $\begin{array}{l}\text { Level of } \\
\text { evidence }\end{array}$ \\
\hline $\begin{array}{l}\text { COVIDSurg } \\
\text { Collaborative }{ }^{(9)} \\
2020 \\
\text { United } \\
\text { Kingdom }\end{array}$ & $\begin{array}{l}\text { Observational } \\
\text { cohort study }\end{array}$ & $\begin{array}{l}\text { To report } 30 \text {-day mortality } \\
\text { and pulmonary complication } \\
\text { rates in patients with } \\
\text { perioperative SARS-CoV-2 } \\
\text { infection. }\end{array}$ & $\begin{array}{l}\text { Pulmonary complications occurred in } 52 \% \text { of the patients, } \\
\text { with cases of pneumonia, acute respiratory failure } \\
\text { syndrome, need for invasive and non-invasive ventilation, } \\
\text { and pulmonary embolism being observed. There was } \\
\text { unplanned admission to the ICU } ¥ \text { for } 102 \text { patients, and } \\
154 \text { required second surgeries. }\end{array}$ & Moderate & II \\
\hline $\begin{array}{l}\text { Di Martino, } \\
\text { et al. }{ }^{(33)} \\
2020 \\
\text { Spain }\end{array}$ & $\begin{array}{l}\text { Retrospective } \\
\text { study }\end{array}$ & $\begin{array}{l}\text { To analyze the impact of } \\
\text { the COVID- } 19 \text { pandemic } \\
\text { on patients undergoing } \\
\text { surgeries at a tertiary-level } \\
\text { hospital in Spain. }\end{array}$ & $\begin{array}{l}\text { Fifteen }(7 \%) \text { cases of SARS-CoV- } 2 \text { infection were } \\
\text { observed among the } 213 \text { surgical patients. Of these, } \\
17 \% \text { were in the elective cancer group, } 1 \% \text { in the } \\
\text { benign disease elective group, and } 7 \% \text { in the urgent } \\
\text { surgery group ( } p<0.001) \text {. Five patients presented severe } \\
\text { respiratory infection, of which } 4 \text { had cancer. There } \\
\text { were } 3 \text { deaths }(1.4 \%) \text {, all due to respiratory infection } \\
\text { complications. }\end{array}$ & Low & IV \\
\hline $\begin{array}{l}\text { Evans, et al. }{ }^{(27)} \\
2020 \\
\text { England }\end{array}$ & $\begin{array}{l}\text { Cross- } \\
\text { sectional } \\
\text { study }\end{array}$ & $\begin{array}{l}\text { To summarize the initial } \\
\text { experience of implementing } \\
\text { elective colorectal cancer } \\
\text { surgery during the } \\
\text { COVID-19 pandemic. }\end{array}$ & $\begin{array}{l}\text { Of the } 23 \text { patients undergoing surgeries, } 10 \text { presented } \\
\text { postoperative complications, but none was serious or } \\
\text { related to COVID-19. There were no cases of unplanned } \\
\text { second surgeries or readmissions. }\end{array}$ & Low & IV \\
\hline $\begin{array}{l}\text { Gruskay, et } \\
\text { al. }{ }^{(34)} \\
2020 \\
\text { USA }\end{array}$ & $\begin{array}{l}\text { Retrospective } \\
\text { case series }\end{array}$ & $\begin{array}{l}\text { To report the results of } \\
\text { a universal test protocol } \\
\text { for COVID-19 in patients } \\
\text { undergoing orthopedic } \\
\text { surgeries during the } \\
\text { coronavirus pandemic and to } \\
\text { describe the postoperative } \\
\text { evolution of asymptomatic } \\
\text { patients positive for } \\
\text { COVID-19. }\end{array}$ & $\begin{array}{l}12 \% \text { of the surgical patients tested positive for COVID-19, } \\
58 \% \text { of them asymptomatic. Postoperative complications } \\
\text { such as pneumonia, urinary tract infection, need for } \\
\text { transfusion, admission to the ICU, need for intubation, } \\
\text { cough, dyspnea, hypoxia and death were observed. In } \\
\text { addition to that, four patients presented alterations in the } \\
\text { postoperative pulmonary x-rays, and all had abnormal } \\
\text { values in the laboratory tests. }\end{array}$ & High & IV \\
\hline $\begin{array}{l}\text { Kayani, et al. }{ }^{(24)} \\
2020 \\
\text { England }\end{array}$ & $\begin{array}{l}\text { Multicenter } \\
\text { cohort study }\end{array}$ & $\begin{array}{l}\text { To establish the effects of } \\
\text { COVID-19 on perioperative } \\
\text { morbidity and mortality and } \\
\text { to determine any risk factors } \\
\text { for increased mortality in } \\
\text { patients with COVID-19 } \\
\text { undergoing hip fracture } \\
\text { surgery. }\end{array}$ & $\begin{array}{l}\text { COVID-19-positive patients had increased postoperative } \\
\text { mortality rates when compared to COVID-19 negative } \\
\text { patients ( } 30.5 \% \text { [25/82] vs } 10.3 \% \text { [35/340], p<0.001). The } \\
\text { following postoperative complications were observed: } \\
\text { respiratory infection, acute kidney injury, septic shock, } \\
\text { myocardial infarction, thromboembolistic disease, ARDS", } \\
\text { multiple organ dysfunction, severe metabolic acidosis, } \\
\text { and coagulation dysfunction. }\end{array}$ & Low & II \\
\hline $\begin{array}{l}\text { LeBrun, et } \\
\text { al. }{ }^{(25)} \\
2020 \\
\text { USA }^{\S}\end{array}$ & $\begin{array}{l}\text { Multicenter } \\
\text { retrospective } \\
\text { cohort study }\end{array}$ & $\begin{array}{l}\text { To evaluate the outcomes } \\
\text { of hospitalized hip fracture } \\
\text { patients treated during the } \\
\text { COVID-19 pandemic in New } \\
\text { York City. }\end{array}$ & $\begin{array}{l}\text { Among the } 59 \text { patients undergoing hip fracture surgery, } \\
15 \% \text { tested positive for COVID-19, } 7 \text { in the preoperative } \\
\text { period and } 2 \text { in the postoperative period, and one was } \\
\text { presumed positive due to death related to COVID-19. } \\
\text { The postoperative complications described were the } \\
\text { following: cough, fever, hypoxia, hypotension, need } \\
\text { for complementary oxygen through nasal cannula or } \\
\text { intubation, radiological alterations and death. }\end{array}$ & Low & II \\
\hline $\begin{array}{l}\text { Lei, et al. }{ }^{(15)} \\
2020 \\
\text { China }\end{array}$ & $\begin{array}{l}\text { Multicenter } \\
\text { retrospective } \\
\text { study }\end{array}$ & $\begin{array}{l}\text { To describe the clinical } \\
\text { characteristics and } \\
\text { outcomes of patients } \\
\text { undergoing surgeries during } \\
\text { the COVID-19 infection } \\
\text { incubation period. }\end{array}$ & $\begin{array}{l}34 \text { patients were operated on, and all developed } \\
\text { COVID- } 19 \text { pneumonia soon after surgery. The common } \\
\text { symptoms included fever, fatigue and dry cough. The } \\
\text { complications presented included the following: ARDS", } \\
\text { shock, secondary infection, arrhythmia, acute cardiac } \\
\text { injury, acute kidney injury. } 15 \text { patients needed admission } \\
\text { to the ICU } \text { and } 7 \text { died, all after admission to the ICU }\end{array}$ & Moderate & IV \\
\hline
\end{tabular}




\begin{tabular}{|c|c|c|c|c|c|}
\hline ID $^{*}$ & Method & Objective & Main Results (postoperative complications) & $\mathrm{JBI}^{+}$ & $\begin{array}{c}\text { Level of } \\
\text { evidence }\end{array}$ \\
\hline $\begin{array}{l}\text { Lepre, et al. }{ }^{\left({ }^{0}\right)} \\
2020 \\
\text { Italy }\end{array}$ & Case report & $\begin{array}{l}\text { To highlight the possibility } \\
\text { of infection by COVID-19 } \\
\text { during the postoperative } \\
\text { period of patients admitted } \\
\text { for emergency surgical } \\
\text { procedures. }\end{array}$ & $\begin{array}{l}\text { Female patient, undergoing a laparotomy for ileocolic } \\
\text { resection, diagnosed with COVID-19 infection on the } \\
3^{\text {rd }} \text { POT. The patient presented } \mathrm{AT}^{* *} \text { over } 38^{\circ} \mathrm{C} \text {, with } \\
\text { persistence of fever until the } 14^{\text {th }} \mathrm{PO} \text {. Laboratory and } \\
\text { imaging alterations were seen from the } 1^{\text {st }} \mathrm{PO} \text { and } \\
7^{\text {th }} \mathrm{PO} \text {, respectively. She presented diarrhea from the } \\
6^{\text {th }} \mathrm{PO} \text {. Postoperative fever must be valued, even in the } \\
\text { absence of other symptoms. It can be related to surgical } \\
\text { complications or respiratory complications secondary or } \\
\text { not to COVID-19. }\end{array}$ & Low & v \\
\hline $\begin{array}{l}\text { McDermott, et } \\
\text { al. }{ }^{(36)} \\
2020 \\
\text { Ireland }\end{array}$ & $\begin{array}{l}\text { Letter to the } \\
\text { editor }\end{array}$ & $\begin{array}{l}\text { To present the perioperative } \\
\text { outcomes of patients } \\
\text { undergoing urological } \\
\text { surgeries during the onset of } \\
\text { the SARS-CoV-2 pandemic. }\end{array}$ & $\begin{array}{l}\text { Seven surgical patients }(7 / 101,7 \%) \text { developed symptoms } \\
\text { of SARS-CoV-2 infection during the postoperative } \\
\text { period, three }(3 / 101,3 \%) \text { diagnosed with symptomatic } \\
\text { SARS-CoV-2 infection. These three patients developed } \\
\text { postoperative pulmonary complications and one of them } \\
\text { died. The complications were evidenced by imaging } \\
\text { findings consistent with SARS-CoV- } 2 \text { infection, including } \\
\text { pleural effusion, ground-glass opacity, and nodular } \\
\text { consolidations in lobules. }\end{array}$ & Moderate & V \\
\hline $\begin{array}{l}\text { Moliere e } \\
\text { Veillon(26) } \\
2020 \\
\text { France }\end{array}$ & $\begin{array}{l}\text { Retrospective } \\
\text { cohort study }\end{array}$ & $\begin{array}{l}\text { To evaluate the frequency } \\
\text { of COVID-19 in a cohort of } \\
\text { newly operated on patients, } \\
\text { performing imaging exams } \\
\text { due to acute symptoms, and } \\
\text { to evaluate the role of chest } \\
\text { computed tomography in this } \\
\text { setting. }\end{array}$ & $\begin{array}{l}\text { Of } 46 \text { patients operated on with acute postoperative } \\
\text { symptoms, } 17 \% \text { were diagnosed with COVID- } 19 \text {. Of } \\
\text { these, } 62 \% \text { required mechanical ventilation and } 25 \% \\
\text { died. All had abnormal chest CT, } 87 \% \text { with typical findings } \\
\text { of COVID- } 19 \text {. The most frequent complications were } \\
\text { hyperthermia, cough, dyspnea, need for intubation, and } \\
\text { death. }\end{array}$ & Moderate & II \\
\hline $\begin{array}{l}\text { Rescigno, et } \\
\text { al. }{ }^{(31)} \\
2020 \\
\text { United } \\
\text { Kingdom }\end{array}$ & Case report & $\begin{array}{l}\text { To describe a cardiac } \\
\text { surgery with a poor outcome } \\
\text { due to postoperative } \\
\text { COVID-19 infection, in } \\
\text { addition to changes in } \\
\text { the practice during the } \\
\text { pandemic. }\end{array}$ & $\begin{array}{l}\text { Male patient undergoing coronary artery bypass surgery. } \\
\text { In the postoperative period, the patient evolved with } \\
\text { respiratory complications attributed to COVID-19, such as } \\
\text { hypoxia, dyspnea and fever in the } 1^{\text {st }} \text { PO", with evolution } \\
\text { to death in the } 9^{\text {th }} \text { POा. The patient was not tested during } \\
\text { the preoperative period, and the waiting time in the } \\
\text { hospital was clearly too long. }\end{array}$ & Moderate & V \\
\hline $\begin{array}{l}\text { Seretis, et } \\
\text { al. }{ }^{(28)} \\
2020 \\
\text { United } \\
\text { Kingdom }\end{array}$ & $\begin{array}{l}\text { Cross- } \\
\text { sectional } \\
\text { study }\end{array}$ & $\begin{array}{l}\text { To present the experience } \\
\text { related to postoperative } \\
\text { morbidity and mortality } \\
\text { associated with COVID-19 } \\
\text { after emergency } \\
\text { gastrointestinal surgery. }\end{array}$ & $\begin{array}{l}\text { A total of } 100 \text { patients were analyzed. The overall } \\
\text { postoperative respiratory complication rate was } 5 \% \text {, with } \\
\text { an infection rate of } 3 \% \text { for COVID- } 19 \text {. Eleven patients } \\
\text { had non-respiratory postoperative complications, } \\
\text { including urinary tract infection, surgical wound infection } \\
\text { and central catheter-related infection, acute coronary } \\
\text { syndrome and cardiac arrhythmia. Five patients } \\
\text { developed postoperative respiratory complications, } \\
\text { including changes in the respiratory tract, pulmonary } \\
\text { embolism and respiratory failure. }\end{array}$ & Low & IV \\
\hline $\begin{array}{l}\text { Yu, et al. }{ }^{(32)} \\
2020 \\
\text { China }\end{array}$ & Case report & $\begin{array}{l}\text { To present the experiences } \\
\text { obtained with a patient } \\
\text { who presented a severe } \\
\text { burst-type lumbar fracture } \\
\text { complicated by an occult } \\
\text { SARS-CoV-2 infection. }\end{array}$ & $\begin{array}{l}\text { Male patient, evaluated during the COVID-19 incubation } \\
\text { period. On the } \text { 3 }^{\text {rd }} \text { PO", the patient developed chills and } \\
\text { high fever. A chest computed tomography scan showed } \\
\text { ground-glass opacity in the lower part of the right lung } \\
\text { and the test for SARS-CoV-2 was positive. }\end{array}$ & Low & v \\
\hline $\begin{array}{l}\text { Yang, et al. } .^{(35)} \\
2020 \\
\text { China }\end{array}$ & Case series & $\begin{array}{l}\text { To report the characteristics } \\
\text { and prognosis of three } \\
\text { women diagnosed with } \\
\text { COVID-19 after oncological } \\
\text { gynecological surgeries. }\end{array}$ & $\begin{array}{l}\text { SARS-CoV-2 infection was observed in three patients } \\
\text { during the postoperative period. The main complications } \\
\text { reported were fever (within } 2 \text { days after the surgery), } \\
\text { cough and hypoxemia. In addition to that, changes were } \\
\text { observed in the imaging exams, compatible with viral } \\
\text { pneumonia ten days after the surgery. }\end{array}$ & Low & IV \\
\hline $\begin{array}{l}\text { Zhao, et al.(29) } \\
\quad 2020 \\
\text { China }\end{array}$ & $\begin{array}{l}\text { Cross- } \\
\text { sectional } \\
\text { study }\end{array}$ & $\begin{array}{l}\text { To retrospectively review } \\
34 \text { patients with acute } \\
\text { abdomen who underwent } \\
\text { emergency surgeries during } \\
\text { the COVID-19 outbreak. }\end{array}$ & $\begin{array}{l}\text { Six cases of pneumonia due to COVID-19 were identified. } \\
\text { The patients with COVID-19 presented worse liver } \\
\text { function and coagulation indicators and longer hospital } \\
\text { stays. Postoperative complications occurred in two } \\
\text { patients: one had aspiration pneumonia and the other } \\
\text { presented multiple organ dysfunction. Both required } \\
\text { mechanical ventilation, and one of them evolved to death. }\end{array}$ & Moderate & IV \\
\hline
\end{tabular}

${ }^{*} \mathrm{ID}=$ Identification; ${ }^{+} \mathrm{JBI}=$ Methodological quality assessment using the Joanna Briggs Institute tool, being considered as with high risk of bias when the study reached a "yes" score below 49\%, moderate when the "yes" score reached $50 \%$ to $69 \%$, and low when the study reached a "yes" score above $70 \%$; ${ }^{\circ} \mathrm{ICU}=$ Intensive Care Unit; sUSA = United States of America; "ARDS = Acute Respiratory Disease Syndrome; "PO = Postoperative; *AT = Axillary Temperature

Figure 4 - Synthesis chart of the studies included to compose the final sample of this integrative review $(n=15)$. Ribeirão Preto, SP, Brazil, 2020 


\section{Discussion}

This study synthesized the evidence related to the postoperative complications in adult patients undergoing surgical procedures with SARS-CoV-2 infection and verified that the most reported complications in the primary studies included in this review were related to the respiratory system and associated with high mortality rates among the patients undergoing surgeries. Cough, dyspnea and hypoxia, image changes compatible with the COVID-19 disease, and the need for invasive mechanical ventilation were among the most frequently found in the studies analyzed.

Respiratory complications are common in the postoperative period in general, mainly due to the anesthetic procedure. In general anesthesia, given the need for orotracheal intubation, changes occur in the pulmonary system due to changes in respiratory impulse and muscle function in the anesthetized patient, reducing lung volumes and, in many cases, leading to complications such as atelectasis. The respiratory system can take up to six weeks to return to its baseline condition after general anesthesia for major surgeries ${ }^{(38)}$.

However, the incidence of postoperative respiratory complications during the pandemic is even higher. A multicenter international cohort study, carried out between January and March 2020 in 235 hospitals from 24 countries, with 1,128 patients undergoing surgeries with confirmed infection by SARS-CoV-2, found a $51.2 \%$ incidence of pulmonary complications ${ }^{(9)}$. This rate is higher than that identified in a multicenter cohort study, carried out pre-pandemic from 2014 to 2015, in 211 hospitals from 28 European countries with 21,694 adult patients undergoing general anesthesia, in which the incidence of postoperative pulmonary complications was $7.6 \%{ }^{(39)}$.

Among the risk factors for the development of respiratory complications in the postoperative period, comorbidities (systemic arterial hypertension, chronic obstructive pulmonary disease and cancer) stand out, as well as extrinsic factors such as smoking and the surgical procedure itself, which can lead to impairment of the immune system cells ${ }^{(40-41)}$. Added to these factors, the infection by the new coronavirus presents itself as an additional risk factor for worsening of the postoperative complications, since SARS-CoV-2 presents tropism for the cells of the respiratory system ${ }^{(9,42-45)}$ and increases the pro-inflammatory cytokines and chemokines levels, correlated with disease severity ${ }^{(46-47)}$.

The signs of SARS-CoV-2 infection in the postoperative period can manifest themselves very similarly to common infections, such as surgical site infections, hindering COVID-19 diagnosis. Therefore, fever episodes in the postoperative period, even if incidental and without the presence of other signs and symptoms, must be carefully investigated, as they can be related to surgical or respiratory complications arising from SARS-CoV-2 or from another microorganism infection $^{(30,36)}$.

When perioperative SARS-CoV-2 infection is identified, the prognosis tends to be worse, with a significant increase in the mortality rates, length of stay and need for mechanical ventilation, either invasive or not. Therefore, preoperative screening is recommended to detect SARS-CoV-2 infection in all patients undergoing elective surgical procedures. However, it is known that this practice is not possible in all surgical services. In addition to that, the virus incubation time and the possibility of perioperative infection must be taken into account during screening, and postoperative testing is also recommended(24,29,32,35-36). For this reason, a number of studies suggest that each case be evaluated individually, in relation to the risks associated with perioperative SARS-CoV-2 infection, when compared to the risks of delaying the performance of surgical procedures. Male patients aged 70 years old or more, with comorbidities, and patients classified as ASA (American Society of Anesthesiologists) from 3 to 5 , undergoing oncologic surgeries, major surgeries or emergency surgeries, are the most vulnerable to adverse outcomes ${ }^{(9,45)}$.

This synthesis also evidenced other complications among the surgical patients infected with SARS-CoV-2, mainly cardiovascular complications such as arrhythmia, acute cardiac injury and acute myocardial infarction. Corroborating these results, a recent study showed that SARS-CoV-2 has a pathogenicity that can increase myocardial damage ${ }^{(48)}$. The results of this research showed cases of acute cardiac injury, shock and arrhythmia in $7.2 \%, 8.7 \%$ and $16.7 \%$ of the infected patients, respectively, being more prevalent among those who needed intensive care. Based on these data, careful attention must be given to cardiovascular protection during treatment for COVID-19(49), especially in the postoperative period.

The Nursing team plays a leading role in the care provided to surgical patients. Perioperative Nursing care based on scientific evidence is essential to prevent postoperative complications ${ }^{(50-51)}$ and also to prevent and reduce the transmission of SARS-CoV-2 in surgical environments.

The need of new research studies on the subject matter is highlighted, pointing out the effects of the SARSCoV-2 infection on the prognosis of surgical patients, so that the health team can intervene early and ensure patient safety in the postoperative period. 
Among the weaknesses of this study, it is highlighted that most of the articles analyzed addressed problems of a respiratory nature, which can hinder the analysis of other complications experienced by surgical patients with SARS-CoV-2. It is also noteworthy that, of the 15 studies, 11 presented a classification of evidence level between IV and $\mathrm{V}$, and that seven had a vulnerable methodological quality, which can compromise generalization of the results to other contexts. Among the knowledge gaps identified, there was lack of studies that addressed complications of other natures, in addition to the respiratory system. New studies with robust methodological approaches and that comprehensively identify systemic complications are recommended.

\section{Conclusion}

Considering the diverse evidence synthesized on the postoperative complications that affected adult patients infected with SARS-CoV-2 and undergoing surgeries, it is concluded that the main complications are related to the respiratory system, with increased mortality rates, need for hospitalization in intensive care unit and prolonged hospital stay. This occurrence can be explained by the fact that SARS-CoV-2 has greater affinity with respiratory epithelial cells. In addition to that, complications related to the cardiovascular system and other systemic complications were observed in this population.

The importance of rigorous preoperative screening that meets at least the majority, but preferably all patients undergoing surgical procedures, is highlighted, taking into account the incubation period of the virus, monitoring and tracking of confirmed cases in the post-operative period, in order to reduce the occurrence of complications related to the SARS-CoV-2 infection.

\section{References}

1. World Health Organization. Clinical management of severe acute respiratory infection (SARI) when COVID-19 disease is suspected. [Internet]. Geneva: WHO; 2020 [cited 2020 Nov 07]. Available from: https://apps.who. int/iris/handle/10665/331446

2. Agência Nacional de Vigilância Sanitária (BR). Nota técnica GVIMS/GGTES/ANVISA no 04/2020: Orientações para serviços de saúde: medidas de prevenção e controle que devem ser adotadas durante a assistência aos casos suspeitos ou confirmados de infecção pelo novo coronavírus (SARS-CoV-2) - atualizada em 25/02/2021. [Internet]. Brasília: ANVISA; 2021 [cited 2021 Jun 05]. Available from: https://portaldeboaspraticas.iff.fiocruz. br/wp-content/uploads/2021/03/NOTA-TECNICA-GVIMS_ GGTES_ANVISA-04_2020-25.02-para-o-site-1.pdf
3. Li G, Fan Y, Lai Y, Han T, Li Z, Zhou P, et al. Coronavirus infections and immune responses. J Med Virol. 2020 Apr;92(4):424-32. doi: http://doi.org/10.1002/jmv.25685 4. World Health Organization. Critical preparedness, readiness and response actions for COVID-19. [Internet]. Geneva: WHO; 2021 [cited 2021 Jun 05]. Available from: https://www.who.int/publications/i/item/criticalpreparedness-readiness-and-response-actions-forcovid-19

5. Kissler SM, Tedijanto C, Goldstein E, Grad YH, Lipsitch M. Projecting the transmission dynamics of SARS-CoV-2 through the postpandemic period. Science. 2020 May 22;368(6493):860-8. doi: http://doi.org/10.1126/science. abb5793

6. Tuite AR, Fisman DN, Greer AL. Mathematical modelling of COVID-19 transmission and mitigation strategies in the population of Ontario, Canada. CMAJ. 2020 May 11;192(19):E497-E505. doi: https://doi.org/10.1503/ cmaj. 200476

7. World Health Organization. Coronavirus disease 2019 (COVID-19) situation report - 74. [Internet]. Geneva: WHO; 2020 [cited 2021 May 30]. Available from: https://www.who.int/docs/default-source/coronaviruse/ situation-reports/20200403-sitrep-74-covid-19-mp. pdf?sfvrsn=4e043d03_14

8. Hojaij FC, Chinelatto LA, Boog GHP, Kasmirski JA, Lopes JVZ, Sacramento FM. Surgical practice in the current COVID-19 pandemic: a rapid systematic review. Clinics (São Paulo). 2020;75:e1923. doi: http://doi.org/10.6061/ clinics/2020/e1923

9. COVIDSurg Collaborative. Mortality and pulmonary complications in patients undergoing surgery with perioperative SARS-CoV-2 infection: an international cohort study. Lancet. 2020 Jul 4;396(10243):27-38. doi: http://doi.org/10.1016/S0140-6736(20)31182-X

10. Spinelli A, Pellino G. COVID-19 pandemic: perspectives on an unfolding crisis. Br J Surg. 2020 Jun; 107(7): 785-7. doi: http://doi.org/10.1002/bjs.11627

11. Besnier E, Tuech JJ, Schwarz L. We asked the experts: Covid-19 outbreak: is there still a place for scheduled surgery? "Reflection from pathophysiological data". World J Surg. 2020 Apr;44:1695-8. doi: http://doi.org/10.1007/ s00268-020-05501-6

12. Huang C, Wang Y, Li X, Ren L, Zhao J, Hu Y, et al. Clinical features of patients infected with 2019 novel coronavirus in Wuhan, China. Lancet. 2020 Feb;395(10223):497-506. doi: https://doi.org/10.1016/S0140-6736(20)30183-5 13. Li J, Gao R, Wu G, Wu X, Liu Z, Wang H, et al. Clinical characteristics of emergency surgery patients infected with coronavirus disease 2019 (COVID-19) pneumonia in Wuhan, China. Surgery. 2020 Sep;168(3):398-403. doi: http://doi.org/10.1016/j.surg.2020.05.007 
14. Lei S, Jiang F, Su W, Chen C, Chen J, Mei W, et al. Clinical characteristics and outcomes of patients undergoing surgeries during the incubation period of COVID-19 infection. EClinicalMedicine. 2020 Apr;21(100331):1-8. doi: https://doi.org/10.1016/j. eclinm.2020.100331

15. Aminian A, Safari S, Razeghian-Jahromi A, Ghorbani M, Delaney CP. COVID-19 outbreak and surgical practice: unexpected fatality in perioperative period. Ann Surg. 2020 Jul;272(1):e27-9. doi: http://doi.org/10.1097/ SLA. 0000000000003925

16. Mendes KDS, Silveira RCCP, Galvão CM. Integrative literature review: a research method to incorporate evidence in health care and nursing. Texto Contexto Enferm. 2008 out/dez;17(4):58-64. doi: https://doi. org/10.1590/S0104-07072008000400018

17. Ministério da Saúde, (BR). Secretaria de Ciência, Tecnologia e Insumos Estratégicos. Departamento de Ciência e Tecnologia. Diretrizes metodológicas: elaboração de revisão sistemática e metanálise de estudos observacionais comparativos sobre fatores de risco e prognóstico. [Internet]. Brasília: Ministério da Saúde; 2014 [cited 2021 Jan 27]. Available from: http:// bvsms.saude.gov.br/bvs/ct/PDF/diretrizes_metodologias_ estudos_observacionais.pdf

18. Mendes KDS, Silveira RCCP, Galvão CM. Use of the bibliographic reference manager in the selection of primary studies in integrative reviews. Texto Contexto Enferm. 2019 Fev 14;28:e20170204. doi: https://doi. org/10.1590/1980-265X-TCE-2017-0204

19. Silveira RCCP, Reis PED, Ferreira EB, Braga FTMM, Galvão CM, Clark AM. Dressings for the central venous catheter to prevent infection in patients undergoing hematopoietic stem cell transplantation: a systematic review and meta-analysis. Support Care Cancer. 2020 Feb;28:425-38. doi: https://doi.org/10.1007/s00520019-05065-9

20. Aromataris E, Munn Z, editors. JBI Manual for Evidence Synthesis. [Internet]. Adelaide: JBI; 2020 [cited 2021 Jan 27]. Available from: https://synthesismanual.jbi.global 21. Polmann H, Melo G, Conti Réus J, Domingos FL, Souza BDM, Padilha AC, et al. Prevalence of dentofacial injuries among combat sports practitioners: a systematic review and meta-analysis. Dent Traumatol. 2020 Apr;36(2):12440. doi: http://doi.org/10.1111/edt.12508

22. Melnyk BM. Level of evidence plus critical appraisal of its quality yields confidence to implement evidence-based practice changes. Worldviews Evid Based Nurs. 2016 Oct;13(5):337-9. doi: http://doi.org/10.1111/wvn.12181 23. Melnyk BM, Fineout-Overholt E. Evidence-based practice in nursing and healthcare: a guide to best practice. $4^{\text {th }}$ ed. Philadelphia: Wolters Kluwer; 2019.
24. Kayani B, Onochie E, Patil V, Begum F, Cuthbert R, Ferguson $D$, et al. The effects of COVID-19 on perioperative morbidity and mortality in patients with hip fractures. Bone Joint J. 2020 Sep;102-B(9):1136-45. doi: http:// doi.org/10.1302/0301-620X.102B9.BJJ-2020-1127.R1 25. LeBrun DG, Konnaris MA, Ghahramani GC, Premkumar A, DeFrancesco CJ, Gruskay JA, et al. Hip fracture outcomes during the COVID-19 pandemic: early results from New York. J Orthop Trauma. 2020 Aug;34(8):40310. doi: http://doi.org/10.1097/BOT.0000000000001849 26. Moliere S, Veillon F. COVID-19 in Post-Operative Patients: Imaging Findings. Surg Infect (Larchmt). 2020 Jun;21(5):416-21. doi: http://doi.org/10.1089/ sur.2020.169

27. Evans S, Taylor C, Antoniou A, Aggarwal T, Burns $\mathrm{E}$, Jenkins $\mathrm{JT}$, et al. Implementation of a clinical pathway for the surgical treatment of colorectal cancer during the COVID-19 pandemic. Colorectal Dis. 2020 Sep;22(9):1002-5. doi: http://doi.org/10.1111/ codi. 15247

28. Seretis C, Archer L, Lalou L, Yahia S, Katz C, Parwaiz I, et al. Minimal impact of COVID-19 outbreak on the postoperative morbidity and mortality following emergency general surgery procedures: results from a 3-month observational period. Med Glas (Zenica). 2020 Aug 1;17(2):275-8. doi: http://doi.org/10.17392/1229-20 29. Zhao N, Wu L, Cheng Y, Zheng H, Hu P, Hu C, et al. The effect of emergency surgery on acute abdomen patients with COVID-19 pneumonia: a retrospective observational study. Aging (Albany NY). 2020 Aug 15;12(15):15771-83. doi: http://doi.org/10.18632/aging.103839

30. Lepre L, Costa G, Virno VA, Dalsasso G, Campa RD, Clavarino $F$, et al. Acute care surgery and post-operative COVID-19 pneumonia: a surgical and environmental challenge. ANZ J Surg. 2020 Jun;90(6):1160-1. doi: http://doi.org/10.1111/ans.15962

31. Rescigno G, Firstenberg M, Rudez I, Uddin M, Nagarajan K, Nikolaidis N. A case of postoperative Covid-19 infection after cardiac surgery: lessons learned. Heart Surg Forum. 2020 Apr 21;23(2):E231-E233. doi: http://doi.org/10.1532/hsf.3011

32. Yu S, Zhang $H$, Chen $W$, Wan S, Zhang $Y$, Xiong $X$, et al. Lessons from a lumbar burst fracture patient infected with SARS-CoV-2. Aging (Albany NY). 2020 Jun 22;12(12):11259-262. doi: 10.18632/aging.103414 33. Di Martino M, Septiem JG, González RM, Nova JLM, Rodríguez $\mathrm{AH}$, Bonito $\mathrm{AC}$, et al. Elective surgery during the SARS-CoV-2 pandemic (COVID-19): a morbimortality analysis and recommendations on patient prioritisation and security measures. Cir Esp. 2020 Nov; 98(9):525-32. doi: http://doi.org/10.1016/j. ciresp.2020.04.029

34. Gruskay JA, Dvorzhinskiy A, Konnaris MA, LeBrun DG, Ghahramani GC, Premkumar A, et al. Universal testing 
for COVID-19 in essential orthopaedic surgery reveals a high percentage of asymptomatic infections. J Bone Joint Surg Am. 2020 Aug 19;102(16):1379-88. doi: http://doi. org/10.2106/JBJS.20.01053

35. Yang S, Zhang Y, Cai J, Wang Z. Clinical characteristics of COVID-19 after gynecologic oncology surgery in three women: a retrospective review of medical records. Oncologist. 2020 Jun;25(6):e982-e985. doi: http://doi. org/10.1634/theoncologist.2020-0157

36. McDermott A, O'Kelly J, Barra E, Fitzpatrick F, Little DM, Davis NF. Perioperative outcomes of urological surgery in patients with SARS-CoV-2 infection. Eur Urol. 2020 Jul;78(1):118-20. doi: http://doi.org/10.1016/j. eururo.2020.05.012

37. Moher D, Liberati A, Tetzlaff J, Altman DG, PRISMA Group. Preferred reporting items for systematic reviews and meta-analyses: the PRISMA statement. PLoS Med. 2009 Jul 21;6(7):e1000097. doi: http://doi.org/10.1371/ journal.pmed.1000097

38. Miskovic A, Lumb AB. Postoperative pulmonary complications. Br J Anaesth. 2017 Mar 1;118(3):31734. doi: http://doi.org/10.1093/bja/aex002

39. Kirmeier E, Eriksson LI, Lewald H, Fagerlund MJ, Hoeft A, Hollmann M, et al. Post-anaesthesia pulmonary complications after use of muscle relaxants (POPULAR): a multicentre, prospective observational study. Lancet Respir Med 2019 Feb;7(2):129-40. doi: http://doi. org/10.1016/S2213-2600(18)30294-7

40. Simsek E, Karaman Y, Gonullu M, Tekgul Z, Cakmak $M$. The effect of passive exposure to tobacco smoke on perioperative respiratory complications and the duration of recovery. Rev Bras Anestesiol. 2016 Sep-Oct;66(5):492-8. doi: http://doi.org/10.1016/j.bjan.2015.03.003

41. Amodeo G, Bugada D, Franchi S, Moschetti G, Grimaldi $S$, Panerai $A$, et al. Immune function after major surgical interventions: the effect of postoperative pain treatment. J Pain Res. 2018 Jul;11:1297-305. doi: http://doi. org/10.2147/JPR.S158230

42. Zorzetto R. Os danos do coronavírus. [Internet]. Rev Pesquisa Fapesp. 1 abr 2020 [cited 2020 Dec 06]. Available from: https://revistapesquisa.fapesp.br/osdanos-do-coronavirus/

43. Perrotta F, Matera MG, Cazzola M, Bianco A. Severe respiratory SARS-CoV2 infection: does $A_{C E}$ receptor matter? Respir Med. 2020 Jul;168:105996. doi: http:// doi.org/10.1016/j.rmed.2020.105996

44. Silva ALO, Moreira JC, Martins S. COVID-19 and smoking: a high-risk association. [Internet]. Rio de Janeiro: FIOCRUZ; 2020 [cited 2021 Mar 03]. Available from: http://dx.doi.org/10.1590/0102-311X00072020 45. Fernandez-Bustamante A, Frendl G, Sprung J, Kor DJ, Subramaniam B, Ruiz RM, et al. Postoperative pulmonary complications, early mortality, and hospital stay following noncardiothoracic surgery: a multicenter study by the perioperative research network investigators. JAMA Surg. 2017 Feb 1;152(2):157-66. doi: http://doi.org/10.1001/ jamasurg.2016.4065

46. Chien JY, Hsueh PR, Cheng WC, Yu CJ, Yang PC. Temporal changes in cytokine/chemokine profiles and pulmonary involvement in severe acute respiratory syndrome. Respirology. 2006 Nov;11(6):715-22. doi: http://doi.org/10.1111/j.1440-1843.2006.00942.x

47. Law HKW, Cheung CY, Ng HY, Sia SF, Chan YO, Luk $\mathrm{W}$, et al. Chemokine up-regulation in SARS-coronavirusinfected, monocyte-derived human dendritic cells. Blood. 2005 Oct;106(7):2366-74. doi: http://doi.org/10.1182/ blood-2004-10-4166

48. Wang D, Hu B, Hu C, Zhu F, Liu X, Zhang J, et al. Clinical characteristics of 138 hospitalized patients with 2019 novel coronavirus-infected pneumonia in Wuhan, China. JAMA. 2020 Mar; 323(11):1061-9. doi: http:// doi.org/10.1001/jama.2020.1585

49. Yang $X, Y u ~ Y, X u J$, Shu $H$, Xia J, Liu $H$, et al. Clinical course and outcomes of critically ill patients with SARSCoV-2 pneumonia in Wuhan, China: a single-centered, retrospective, observational study. Lancet Respir Med. 2020 May;8(5):475-81. doi: http://doi.org/10.1016/ S2213-2600(20)30079-5

50. Rocha LP, Castanheira JS, Barlem ELD, Carvalho DP, Gutierres ED, Passos CM, et al. Paciente cirúrgico no contexto da pandemia de COVID- 19. [Internet]. Rio Grande: FURG/EENF; 2020 [cited 2021 Jun 03]. Available from: https://eenf.furg.br/images/COVID/Paciente_ Cirurgico_no_Contexto_da_Pandemia_de_COVID-19.pdf 51. Souza TM, Carvalho R, Paladino CM. Diagnósticos, prognósticos e intervenções de enfermagem na sala de recuperação pós-anestésica. Rev SOBECC. [Internet]. 2012 [cited 2021 Jun 03];17(4):33-47. Available from: https://revista.sobecc.org.br/sobecc/article/view/187

\section{Authors' Contribution:}

Study concept and design: Renata Cristina de Campos Pereira Silveira. Obtaining data: Erica Favaro, Daiane Rubinato Fernandes, Leticia Genova Vieira, Renata Cristina de Campos Pereira Silveira. Data analysis and interpretation: Erica Favaro, Daiane Rubinato Fernandes, Leticia Genova Vieira. Statistical analysis: Erica Favaro, Leticia Genova Vieira, Renata Cristina de Campos Pereira Silveira. Obtaining financing: Daiane Rubinato Fernandes, Leticia Genova Vieira. Drafting the manuscript: Daiane Rubinato Fernandes, Leticia Genova Vieira, Renata Cristina de Campos Pereira Silveira. Critical review of the manuscript as to its relevant intellectual content: Leticia Genova Vieira, Amanda 
Salles Margatho, Karina Dal Sasso Mendes, Renata Cristina de Campos Pereira Silveira.

All authors approved the final version of the text.

Conflict of interest: the authors have declared that

there is no conflict of interest.

This license lets others distribute, remix, tweak, and build upon your work, even commercially, as long as they credit you for the original creation. This is the most accommodating of licenses offered. Recommended for maximum dissemination and use of licensed materials. 